\title{
Islamophobia and normative sociology
}

\author{
Tariq Modood
}

Lecture in Sociology, read 20 March 2019.

Abstract: The concept of Islamophobia as anti-Muslim culturalism racism is establishing itself in social science and public discourse alike. Yet there is a tendency to focus on Muslims as an 'Other', an ascribed identity, at the expense of Muslim intersubjectivity and agency. 'Othering' analysis also does not attend to how to distinguish between Islamophobia and reasonable criticism of Muslims and Islam. Moreover, the possibility of mutual criticism based on dialogue, as well as group intersubjectivity and agency are important for multicultural recognition and accommodation. The bringing out of the political significance of the latter is illustrative of a sociology which thinks of socio-political problems and solutions as existing within the same intellectual framework. Going further, such normative sociology makes explicit and justifies its normative presuppositions and prizes public intellectual engagement.

Keywords: Islamophobia, cultural racism, Muslims, multiculturalism, public sociology.

Note on the author: Tariq Modood is Professor of Sociology, Politics and Public Policy and the founding Director of the Centre for the Study of Ethnicity and Citizenship at the University of Bristol. He was made an MBE for services to social sciences and ethnic relations in 2001, a Fellow of the Academy of Social Sciences in 2004 and elected a Fellow of the British Academy in 2017. He pioneered the idea of anti-Muslim racism in the 1990s, which has now become the leading interpretation of Islamophobia. He has held over 40 grants and consultancies, has over 35 (co-)authored and (co-)edited books and reports and over 200 articles and chapters. His latest book is Essays on Secularism and Multiculturalism (Rowman and Littlefield International, 2019). T.Modood@bristol.ac.uk, tariqmodood.com 


\section{NORMATIVE SOCIOLOGY}

This article is on presenting an understanding of Islamophobia and distinguishing it from other characterisations. The differences are partly to do with what I am trying to do, with what I shall call 'normative sociology'-something that some will think is an oxymoron, so let me start by addressing the methodological character of my argument. My work in general consists of a hybrid of normative political theory and empirical political sociology, sometimes more of one than the other. This interdisciplinarity is deployed in developing the concepts I use, such as multiculturalism, and in giving empirical or historical accounts, such as the emergence of Muslim identity politics in Britain. The latter are normatively informed by my conceptual framework, which itself is developed by drawing out normative 'isms' which are partly present in the political contexts I am interested in. This can mean accentuating an aspect of a complex context, say, bringing out the multiculturalist element of what may after all be a political pragmatic compromise, reflecting mixed motives and contesting actors. This is done to highlight its normative dimension and those aspects of its normativity which might otherwise be missed - because other observers are not sensitised to look for them or do not have the conceptual tools to identify them - or that I want to claim are novel or are part of a trend and their significance is missed if that is not appreciated. Yet also because my empirical analyses are informed by advocacy, by making, say, a multiculturalist case. Either by arguing in favour of something that has happened (an action, policy or law) or supporting a protest or campaign or recommending a course of action or a policy programme. Sometimes this will be about the details of the case - for example, the wording of a particular law-but mostly it will be about relating it to a larger political idea or framework, such as moderate secularism (Modood 2019). The objects of analysis are typically a political conflict or controversy and the analysis is framed in terms of a normative political theory in order to make the controversy more meaningful in terms of the ideas and discourses involved as well as explain why things are taking the course that they are. Yet it is most important to me to not just leave things there. In theorising about real-world cases, I am not merely 'problematising' or 'deconstructing' them, but pointing to feasible, contextually sensitive solutions. The aim is to be constructive, not just deconstructive or analytical (Dobbernack \& Modood 2015, forthcoming).

This is dependent on how we conceptualise social phenomena. Racialisation, for example, is a normative concept: it is built to be a concept that picks out something negative. If a particular researcher thought it was not negative, they would need to provide a special argument. Of course, someone may use the concept without having any negative feelings about it, but the concept itself is not normatively neutral and the study of it cannot start without it or a critical discussion of it. Similarly, if racialisation 
picks out a negative phenomenon, we need to have some idea of what anti-racialisation or de-racialisation look like; that is, what is the positive that can overcome the negative? How are we to judge the benign from the malign exercises of power and effects of social processes?

That, then, is one kind of normativity that my work and this article hangs on. The other kind of normativity also begins from the fact that we are students of subjectivity and agency - such as that of Muslims and those who may be negative about Muslims. It means that sociology seeks to identify the reasons and not just the possible cause-effect mechanisms. These reasons and discourses should be engaged with. This suggests the kind of normative framework that, for example, should bring out the Islamophobic aspects of some discourses but at the same time allow for engagement with some of their more reasonable aspects, primarily those which can feature as part of intercultural dialogues or civic conversations. These two kinds of normativity, especially the second, make the inquiry interdisciplinary because it connects with a form of contextualised political theory, with forms of normative reasoning.

In developing concepts, the method employed bears some resemblance to Weber's 'ideal types', of which he writes:

An ideal type is formed by the one-sided accentuation of one or more points of view and by the synthesis of a great many diffuse, discrete, more or less present and occasionally absent, concrete individual phenomena, which are arranged according to those one-sidedly emphasised viewpoints into a unified analytical construct. ... In its conceptual purity, this mental construct ... cannot be found empirically anywhere in reality. (Shils \& Finch 1997: 90)

Weber insisted, however, that ideal types were not normatively ideal; indeed, they had nothing to do with values. When, in order to challenge some abstract political theory, I characterised Western European state-religion arrangements as a form of 'moderate secularism' (Modood 2019), it, like Weber's ideal type, is a descriptive concept rather than a concrete description, but it is not merely a description of norms but conceptualised as norms which are currently achieving worthwhile purposes. Similarly, in relation to multiculturalism I begin not just with phenomena, but phenomena characterised as 'negative', such as exclusion (and so clearly some normative standard is already at work) and which can and should be made inclusive. I point to social facts suggesting how, as it were, the positive is struggling to be born or stay alive. There are genuine processes and movement towards developments, but there are difficulties and obstacles and there is no guarantee that the positive will be achieved. In any case, achievement here will always be relative to a previous time or to another place, not an end-point; it is the nature of a positive ideal that more progress can always be envisaged. This is beginning to drift quite a long way from Weberian ideal types, but nevertheless there is a sense in which 'moderate secularism' (or 'British multiculturalism' 
or 'French political culture') bears similarity to them, at least as an intermediate stage between the negative and the positive.

For Weber, values enter social science simply in the choice of subject matter, say employment rather than the family, or poverty rather than racial inequality, but they are separate from the scientific study of any of those topics. Yet all social science presupposes frameworks/perspectives because any inquiry must have a frame. Different research programmes and frameworks can put questions of family or equality in one way or another, at the centre or not - and this is not just about adequate explanations of what $i s$, nor the means of maintaining or changing it but rather about how we are to conceptualise, say, equality. The conceptualisation is not the result of knowledge or a set of explanations; it is what directs us to a productive line of inquiry or knowledge accumulation. As the inquiry builds up a dynamic, the initial framing can be reviewed and adapted and thus there will be a dialectal relationship; but debates about different frameworks, different ways of conceptualising society, conceptual arguments, are never reducible to questions of empirical knowledge. Such frameworks, however, are likely to have some normative character-should equality only be about income levels or should it also be conceptualised to include questions of respect and recognition? To disfavour the latter because it cannot be measured is to allow methods to dictate concepts and the inquiry. In sum, there must be a bridge between social science and normative inquiry which is not reducible to merely personal choices. Social science must, on my view, therefore encourage engagement with normative questions for the sake of the quality of science rather than draw positivist boundaries around itself.

Another feature in which my approach differs from Weber is that I have only slowly moved in the direction that his and allied methods might be taken to recommend; namely, not just the 'idealisation' or 'conceptualisation' of a contingent, specific case, such as, say, the emergence and growth of capitalism in Western Europe at a specific time, but to construct a model that could capture the character of all capitalisms. Mindful of an Oakeshottian scepticism about cross-cultural and transnational abstract modelling in relation to social and political life (Oakeshott 1962), I tend to worry that such concepts and models may obscure more than they reveal. Perhaps that scepticism is not warranted and perhaps I do not fully abide by it in practice, and so it is safer to describe my approach as developing concepts to understand specific cases such as Britain rather than using that as an opportunity for generalisation and greater abstraction. For these two reasons, my concept formation is perhaps less Weberian and more a form of contextualised political theory. ${ }^{1}$

${ }^{1}$ For political theory methodological discussions of my concept of moderate secularism, see Lægaard (2008, 2009, 2015) and Modood (2009). 
Simon Thompson and I have tried to give an account of such a form of theory (Modood \& Thompson 2018). It is an approach that is not tied to a single national context or political tradition or culture, but it gives significant weight to these contexts and cultures in its theorising in at least three important ways. Firstly, it insists that political ideas and 'isms', including the principles of academic political theory, get their meaning from the contexts they have been extrapolated out of or engaged with. The concept of liberty has a similar but different meaning in the USA, France and Britain. A theorist whose thinking was formed in one of these contexts would reflect that context. When they applied their concept to one of the other countries they would have an imperfect understanding of that context or they could productively revise their concept of liberty. Doing the latter is clearly the way forward, but it means that the second context has changed the concept. Indeed, every engagement with a context, every time the concept of liberty is taken on an outing, it will have to undergo some change to reflect the cross-contextual variety. Thus even abstract principles such as liberty are reflective of the contexts that have been engaged with. So the search for generality is hollow unless it is about accommodating the richness of contextual differences rather than abstracting them out. Second, we argue that theorists should take contexts seriously, as the network of norms, practices and institutions that constitute a context are ones which people have come to identify with - they are not just bits of organisational machinery but are a sociocultural ecology in which people have made and across generations developed identity investments. While this does not mean that contexts cannot be criticised, the fact of those identity investments implies a duty of care on the part of critics. Whilst there will always be a limit to how far this can be practised, the point applies to majority and minority practices alike. My approach, as part of what has come to be characterised as the 'Bristol School of Multiculturalism', emphasises ethnic assertiveness, bottom-up political mobilisation and the constant and dynamic presence of some degree of conflict, but at the same time it is sensitive to the values, practices and ways of doing things within a tradition or ongoing political culture (Levey 2019 and the subsequent symposium in the December 2019 issue of the journal Ethnicities).

The last point I wanted to mention from the article with Thompson is how to understand the possibility of reform and deliberate change. Oakeshott argues that political traditions are 'neither fixed nor finished', have 'no changeless centre' and no part of them is 'immune from change' (Oakeshott 1962: 128). Although he is sometimes misunderstood as a change-averse traditionalist, Oakeshott's point is the opposite: no practice is static and there is no fixed, singular direction of change or progress. Rather, he argues, every political context gives some indication or 'intimation' of what changes are possible, appropriate, necessary and so on. These are matters of judgement not of rational deductive solutions, but again they point to the 
importance of understanding the specificity of a context: reformation means a deeper understanding of the specific case and of what is problematic within it (Modood \& Thompson 2017).

One of the hazards of my approach, which brings together what Weber argued should be kept apart-Weber's social-scientific imperatives and ethical imperativesis that sociologists will find it normative and subjective; while political theorists will object it is too descriptive of certain times and places and not sufficiently justificatory or universal, that it does not sufficiently justify what ought and ought not to exist, in the way that liberalism does. I accept those two sets of criticisms to some degree, but I think it is still of value to social inquiry and to normative analysis, including to those who think the two should be separately pursued. Regardless of its hybridic character, it can make a contribution, albeit in not a pure form, to sociology and political theory, but more importantly it can help to direct political theory to real-world as opposed to abstract, hypothetical problems. Moreover, while it is often backgrounded, I do think most social science, certainly sociology, has a normative character. This is especially evident in sociology centred on class, say for instance on the social and human cost of market-generated inequalities, or of migration policies. It is highly conspicuous of the sociology inspired by the new social movements of the 1960s and 1970s, for example around gender and sexuality. So, an approach which makes explicit and offers some argument in favour of the normative frame in which empirical inquiry is taking place is in an important sense more not less scientific for not being uncritical of its normative orientation.

One of the key values for me of this explicitly interdisciplinary approach, normative sociology or contextualised political theory, is that it lends itself to public intellectual engagement. In my recent book I point to how political theory, if it is to be of assistance in multiculturalist controversies, must come to understand minority claims and protests by engaging in intercultural dialogue (Modood 2019: Chapter 12). ${ }^{2}$ Here not just specificity and an openness to understanding novelty, and to relate to existing norms is important but also one's biography, one's social location, can also be critical. In doing so I contrast my understanding of a public intellectual, whose rootedness and commitments can be critical to giving voice to and addressing the concerns and protests of subordinate groups, with that offered by Edward Said's more romantic portrayal of a public intellectual as 'an exile' (Modood 2019: Chapter 12). Similar to my concern about contextualised theory, I contend that an out-and-out 'outsider'

\footnotetext{
${ }^{2}$ We need, however, to distinguish intercultural dialogue and interculturalism; the latter is often a vehicle for an unwarranted critique of multiculturalism and promotes intercultural encounters at a micro-level, whilst multiculturalists emphasise dialogue at macro and national levels, as explained in Modood (2019: Chapter 12). See also Meer \& Modood (2012), Meer et al. (2016) and Modood (2018).
} 
status is not a good basis for multicultural public intellectual engagement, in which one's commitment to certain peoples and society can be the basis for moderating conflict.

\section{ISLAMOPHOBIA}

Normative sociology is, then, driven by socio-political problems and which thinks of problems and solutions as existing within a common intellectual framework. This framework must be normative, for to identify something as a problem, let alone to address it is to appeal to ideals. Going further, normative sociology uses sociological enquiry to engage with ideals and to justify itself normatively. It thus has an active interdisciplinary relationship with rather than a merely dependent relationship upon political theory. It is also a form of sociology that lends itself to-indeed prizespublic intellectual engagement.

I turn, then, to Islamphobia. The Runnymede Trust (London) launched the public career of the concept of Islamophobia in 1997. It was too much located in the field of religious tolerance and pluralism, and an alternative understanding of Islamophobia that defines it as anti-Muslim racism in the context of multicultural citizenship was pioneered in sociology. This latter concept is establishing itself in social science and public discourse alike. Yet I have some misgivings about the direction that some Islamophobia/Muslim studies are taking. My approach sees racialised ethno-religious group identity as having an 'inside', but in much of social science it is understood as something that is 'constructed from the outside', namely that it is an ascribed identity, constructed as a form of 'Othering'. I think that both these aspects of groupness have a real-world existence and political significance, and cannot be reduced to the Other, but too much of social studies is focused on 'Othering' alone. One benefit of seeing that perceptions and criticisms of Muslims and Islam cannot be reduced to 'Othering' is that it allows us to acknowledge that it is possible to reasonably criticise Muslims. I distinguish between Islamophobia and reasonable criticism of Muslims by emphasising the importance of dialogue. Muslim intersubjectivity and agency, however, are particularly important for multicultural recognition and accommodation. The article is thus a multiculturalist plea for studying Islamophobia (and groups negatively perceived from the outside, generally) within a normative framework which prioritises groups fighting outsider perceptions by boosting insider identifications ('the struggle for recognition'). The form of the discussion may be called 'normative sociology'.

Let us begin with racism. It was not very long ago that Anglophone scholars of racism understood it in terms of biology, and specifically in terms of the black-white binary. At the same time, other scholars, especially in continental Europe, understood 
racism in terms of anti-Semitism, especially in the recent biologised forms that Europe has manifested. When it began to be clear that these two paradigms were failing to capture some contemporary experiences, such as anti-Asian cultural racism in Britain or anti-Arab cultural racism in France, some scholars began to move away from these paradigms (see Modood 1997). Yet, following the assertive Muslim agency triggered by The Satanic Verses affair and other Muslim controversies, as Muslims responded to such hostilities and articulated their misrecognition, they were constantly told that there is no such thing as anti-Muslim racism because Muslims are a religious group and not a race. Hence Muslims could legitimately ask for toleration and religious pluralism but not for inclusion in anti-racist egalitarian analyses and initiatives. While this view continues to be expressed even today, and some deny that there is a racism that could be labelled 'Islamophobia', it no longer has the hegemony it once had.

The origins of the term Islamophobia have been variously traced to an essay by two French Orientalists (Dinet \& ben Ibrahim 1918), to 'a neologism of the 1970s' (Rana 2007: 148), to an early 1990s American periodical (Sherridan 2006), and, indeed, even an article of mine has been in contention (see Modood 1991, quoted in Mr Moo 2006). ${ }^{3}$ While a number of Anglophone authors, including myself, started using the concept of Islamophobia in the late 1980s and early 1990s (not 1970s), it was the Runnymede Trust's Commission on British Muslims and Islamophobia report Islamophobia: A Challenge For Us All (CBMI 1997), which launched the career of the term as a concept of public discourse in Britain and much beyond it. It presented Islamophobia as 'a useful shorthand way of referring to dread or fear of Islam - and therefore to fear or dislike of all or most Muslims' (4). While the report was ground-breaking and played a crucial role in getting people to think about anti-Muslim prejudice, I felt its definition was back-to-front: Islamophobia was not fear of Muslims derived from a fear of Islam, but a hostility to and racialisation of Muslims in the same way as anti-Semitism is anti-Jew racism, not a fear of Jews derived from a fear of Judaism. The Runnymede report did not sufficiently locate Islamophobia as a racism. I continued to write about Islamophobia as a form of cultural racism, which may be built on racism based on physical appearance (for example, colour racism) but was a form of racism in its own right like anti-Semitism. ${ }^{4}$ This also became the

\footnotetext{
${ }^{3} \mathrm{My}$ article in question seems to be the sixth to use the term in 'Islamophobia'. Initially, I was doubtful if 'Islamophobia' was the best term. As Allen (2010: 13) writes: 'Modood wrote about the subject matter of hostility towards Muslims and Islam in a number of articles throughout 1990 and 1991 in particular, The Independent, 5 February 1990, The Times Higher Education Supplement, 30 March, 1990, and The Independent, 19 June 1990. His first recorded use of the term "Islamophobia" was in The Independent, 16 December, 1991. For all articles, see Tariq Modood, Not Easy Being British (Stoke on Trent: Runnymede Trust and Trentham Books, 1992), 69-78.'

${ }^{4}$ I am grateful to Robin Richardson, former Director of The Runnymede Trust, for reminding me that the Trust did emphasise that its work on Islamophobia was a direct follow-up to its work on anti-Semitism, and
} 
approach of UNESCO and I am pleased to see that it has been explicitly embraced by the new, 2017 Runnymede Trust report, Islamophobia: Still a Challenge For Us All (Elahi \& Khan 2017). It is at the centre of the definition offered by the 2018 report of the All-Parliamentary Group on British Muslims (APPG 2018) that has been very widely accepted, albeit not by Prime Minister Theresa May's government and its successor (BBC News 2019).

Here I want to bring together five propositions:

1. Islamophobia is a form of Othering or cultural racism (amongst other things).

2. A racialised group like Muslims cannot be reduced to a race or an 'Other'.

3. Critique of Othering/Islamophobia presupposes non-Othered knowledge of the Other.

4. Critique of Islamophobia presupposes a normative framework which needs to be justified.

5. Islamophobia can be distinguished from reasonable criticism of Islam and Muslims.

I approach Islamophobia as a discourse or as something capable of propositional content. Of course, Islamophobia can also take a structural or institutional form, for example, discriminatory practices in employment. The latter, however, presupposes the discursive form I am analysing; and so I am studying Islamophobia at its most fundamental level. So, those who argue that Islamophobia must be understood in terms of the structures of the state (Massoumi et al. 2017) overlook that we must first, and independently, know what Islamophobia is before we can identify it in state or any other structures (the same point applies in relation to those who see Islamophobia in terms of neoliberalism, capitalism or global hierarchies). My claim is that, if the analysis presented here is correct, it holds independently of what social, political or economic structures Islamophobia can be found in.

\section{Islamophobia is a form of Othering or cultural racism.}

Islamophobia is a form of cultural racism because, while the perception and treatment of Muslims clearly has a religious and cultural dimension, it, equally clearly, bears a physical appearance or ancestral component. For while it is true that 'Muslim' is not a (putative) biological category in the way that 'black' or 'south Asian' (aka 'Paki'), or

within months of the report's publication its reconstituted commission on Islamophobia under Richard Stone was lobbyingfor amendments regarding Islamophobia to draft legislation on racist hate crimes and on racial discrimination. Moreover, that in 2001 it made much use of the concept of anti-Muslim racism as a result of advocacy of persons including Stuart Hall and myself. 
Chinese is, neither was 'Jew' once. In that instance it took a long non-linear history of racialisation to turn an ethno-religious group into a race. More precisely, the latter did not so much replace the former as superimpose itself because, even though no one denied that Jews were a religious community, with a distinctive language(s), culture(s) and religion, Jews still came to be seen as a race, and with horrific consequences. Similarly, Bosnian Muslims were 'ethnically cleansed' because they came to be identified as a 'racial' group, that is to say, as having a perceived line of descent, by people who actually were phenotypically, linguistically and culturally the same as themselves. The ethnic cleanser, unlike an inquistor, wasted no time in finding out what people believed, if and how often they went to a mosque and so on: their victims were racially identified as Muslims in terms of membership based on a perceived line of descent (Modood 2005: Introduction).

Race, then, as I understand it is not just about biology or even 'colour', for, while racialisation has to pick on some features of a people related to physical appearance and ancestry (otherwise racism cannot be distinguished from other forms of groupism), physical appearance need only be a marker, and not necessarily denote a form of determinism. This is illustrated in the conceptualisation of cultural racism as a twostep process (Modood 1997). While biological racism is the antipathy, exclusion and unequal treatment of people on the basis of their physical appearance or other imputed physical differences, saliently in Britain their non-'whiteness', cultural racism builds on biological racism a further discourse which evokes cultural differences from an alleged British or 'civilised' norm to vilify, marginalise or demand cultural assimilation from groups who may also suffer from biological racism. Post-war racism in Britain has been simultaneously culturalist and biological/descent-based, and while the latter is essential to the racism in question, it is, in fact, the less explanatory aspect of a complex contemporary phenomenon. Biological interpretations have not governed what white British people, including racists, have thought or done; how they have stereotyped, treated and related to non-whites; and biological ideas have had increasingly less force both in the context of personal relationships and in the public conceptualisation of groups (Modood 1997). As white people's interactions with nonwhite individuals increased, they did not become necessarily less conscious of group differences, but they were far more likely to ascribe group differences to upbringing, customs, forms of socialisation and self-identity than to biological heredity. ${ }^{5}$

Cultures and cultural practices are usually internally diverse, containing and omitting various 'authentic' elements, and adaptations and mixes. To racially group

\footnotetext{
${ }^{5}$ An interesting question arises as to whether it could be a one-step racism: could colour racism decline and fade away and yet cultural racism — seeing a descent-based people as culturally 'Other' — remain and perhaps even grow?
} 
all Jews or Muslims together as one cultural 'race' or as one ethnoreligious entity is to catch most if not all internal cultural differentiation in that targeted group. For example, a non-religious Muslim might still be targeted as a cultural Muslim or Muslim by community; which of course means Muslim by background; which means birth and ancestry. Hence my point that Muslims, no less than Jews, are identified 'racially' and not simply in terms of religious beliefs or behaviour. Moreover, if we accept that racism does not necessarily involve attributing qualities which inhere in a deterministic law-like way in all members of a group, then we do not have to rule out cultural racism as an example of racism. As such we should guard against the characterisation of racism as a form of 'inherentism' or 'biological determinism' which leaves little space to conceive the ways in which cultural racism draws upon physical appearance as one marker amongst others (Modood 2005: Chapter 1).

\section{A racialised group cannot be reduced to a race.}

While understanding some contemporary treatment of Muslims and aspects of their societal status in terms of 'racialisation' clearly is an advance, we should beware that the conceptualisation of Muslims in the West is not reduced to racialisation or any other 'Othering' theoretical frame such as Orientalism (Said 1978). By definition, 'Othering' sees a minority in terms of how a dominant group negatively and stereotypically imagines that minority as something 'Other', as inferior and/or threatening, and to be excluded. Indeed, the dominant group typically projects its own fears and anxieties onto the minority. Minorities, however, are never merely 'projections' of dominant groups, but have their own subjectivity and agency through which they challenge how they are (mis)perceived and seek to not be defined by others but to supplant negative and exclusionary stereotypes with positive and prideful identities. Oppressive misrecognitions, thus, sociologically imply and politically demand recognition. Our analyses therefore should be framed in terms of a struggle for recognition, an argument I will not repeat here (Modood 2013 [2007]).

The danger of reducing Muslims to racialised identities is particularly high at the moment because the Islamophobic 'Othering' of Muslims is acute and, if anything, rising. This can be seen in how aggressive negative portrayals of Muslims is standard in so much right-wing nationalism, whether in President Trump's Muslim entry bans, Marine Le Pen's 'National Rally' (previously 'National Front'), Alternativ für Deustschland in Germany or in various parties in Central and Eastern Europe, including the Freedom Party in Austria, which even, albeit briefly, entered government in 2019. Discourses about Muslims have been central to the internal debates in UKIP about whether to become a working-class party of welfarism or one defending 'our 
way of life' against the alleged threats of Islamisation ${ }^{6}$. Notable here also is the infamous newspaper article by, now Prime Minister, Boris Johnson in which while allegedly arguing against bans on the burqa which have proliferated across Europe, describes the wearers of this style of dress as 'letter-boxes' and looking like 'bank robbers' (Johnson 2018). Western media routinely present Muslims as unBritish, unFrench, unGerman and so on and with a degree of hostility that no other group in Europe suffers (except perhaps the Roma in parts of Central Europe (Wike et al. 2019)). It is therefore right that scholarly and public attention should be focused on this racialisation of Muslims that is creating a deep, long-term division in our societies which may be very difficult to reverse. Yet, like all ethnic or religious groups, Muslims are not merely created by their oppressors, but have their own sense of identity too. Multicultural inclusivity means understanding, recognising and respecting these identities.

Recognition of course does not mean thinking of Muslims as a group with uniform attributes or a single mindset, all having the same view on religion, personal morality, politics, the international world order and so on. In this respect Muslims are just like any other group - they cannot be understood in terms of a single essence. No one in the social sciences thinks that identities are based on cognitive or behavioural properties that are shared by all who may be members of a relevant group, such as women, black people, gays and lesbians and so on. If group members do not share a common essence, then they cannot be simply demarcated from non-group members because there will be many cases where individuals are not simply on one side of the boundary or the other. So, groups cannot have discrete, nor indeed fixed, boundaries, as these boundaries may vary across time and place, across social contexts and will be the subject of social construction and social change. This 'anti-essentialism' is rightly deployed in the study of Islamophobia and Muslims. It is a powerful way of handling ascriptive discourses, of showing that various popular or dominant ideas about Muslims, just as in the case of women, gays and so on, are not true as such but are aspects of socially constructed images that have been made to stick on to those groups of people because the ascribers are more powerful than the ascribed. Anti-essentialism is an intellectually compelling idea and a powerful resource in the cause of equality.

It is also common, though, for authors to accuse each other of essentialism. This is because there are different versions of anti-essentialism. To pave the way for my third and fourth propositions, I want to briefly rehearse two interpretations which I discussed in my book, Multiculturalism (Modood 2013 [2007]: Chapter 5). The first is the sceptical interpretation that the critique kills the groups as real entities and they only live on as ascriptions or reactions to ascriptions or political make-believe. Rogers Brubaker, for example, argues that 'ethnicity, race and nation are not things in the

${ }^{6}$ Wikipedia: https://en.wikipedia.org/wiki/UK_Independence_Party 
world but perspectives on the world; ways of seeing, interpreting and representing the social world' (Brubaker 2005: 17, 79 and 219). One way to interpret this claim might be to conclude that there is something false, fictitious and illegitimate about appeals to culture, ethnicity and so on in understanding oneself, let alone others or society. Stuart Hall's words sometimes lend themselves to this radical conclusion:

'If we feel we have a unified identity ... it is only because we construct a comforting story or 'narrative of the self' about ourselves. ... The fully unified, completed, secure and coherent identity is a fantasy. (Hall 1992a: 277)

Sceptics do not necessarily want to kill off worthwhile political projects around, say, a black identity or feminism and so some allow for something called 'strategic essentialism' (Spivak 1990; cf Kristeva 1981), where pretending that there is a black or national identity is permitted because of the politics, but analysts know that these identities are only 'necessary fictions' (Hall 1992b: 254). I think, however, groups are not just strategically but conceptually necessary to both social science and to anti-racism or egalitarian politics and so I offered an alternative interpretation of anti-essentialism. I suggested that Wittgenstein's concept of family resemblance offers a way of recognising that, just as it does not make sense to say that games or languages do not exist because they do not share a common, definitional essence (Wittgenstein 1953: para. 108), so the lack of group essences and discrete, bounded populations with unchanging characteristics was not a good reason to assert in an a priori way that groups did not exist. Rather, we had to have a more flexible, looser and variable notion of a group and of group membership that allowed for open-textured and overlapping boundaries and overlapping memberships. If it seems difficult to reconcile this with our a priori concept of group, let us call the entities, 'groupings'. The key point was that, once we stopped demanding that groups measure up to our impossible definitions, we would lose the temptation to conclude that groups suffered from an ontological deficiency, that they were merely 'perspectives upon the world', ontologically no superior to the products of Othering. Another way of putting it is that, just as the complete self-made individual of some liberal theories does not exist, it does not follow that individuals do not exist, that we have to give up 'individual' from social science vocabularies; so similarly with groups.

\section{Critique of Othering presupposes non-Othered knowledge of the Other.}

The value of Othering as a way of studying minorities is that it can be used to challenge blanket generalisations about a minority. Othering sometimes takes the form of attributing certain features to a group, which are alleged to be found in all members of the group. 'All blacks are muggers', 'All Muslims are fanatics' and so on. Theorists of racialisation 
typically add that, even when no explicit biological ideology is in play, these generalisations are being asserted by the racists in a quasi-naturalistic way, that is to say that, like the laws of nature, they brook no exceptions (Modood 1997, 2005: Introduction).

The problem with this is that it is an implausible analysis of racialised thinking. Racists often do admit of counter-examples. 'My best friend is black and no mugger and if only all blacks could be like that but alas they are not.' Moreover, these racialised statements, which identify groups on the basis of their physical appearance, are not necessarily seeking biological or natural bases for the racialised generalisations. The racialiser is unlikely to believe that black mugging and Muslim fanaticism are genetic and much more likely to think that it is something to do with upbringing, family structure, community norms etc., in short what we might call 'culture' in the manner of cultural racism that I have described (Modood 1997). Yes, the concept of Othering has the power to point out to racists that their generalisations do not hold for every member of the putative 'race', that their thinking suffers from quasinaturalism or essentialises a group. However, all the racist has to do to escape the critique is to say that they are not talking about all members but some members or many members or most members, or more precisely, of more members than is true for other groups or society as a whole.

So, to make effective the anti-racist critique one needs to engage with probabilistic statements and that means relating it to what is known or can be researched empirically about the population in question. More fundamentally, the question that my discussion here raises is: when a dominant group attributes certain characteristics to a subordinate group, how do we work out which of those characteristics that are meant to constitute the Otherness of the minority is an imagined and malign projection onto the minority and which is a genuine feature of cultural difference? Another way of putting this is that the analysis of Othering is not a self-sufficient intellectual perspective or disciplinary inquiry, for example, as Orientalism or anti-racism studies. It is dependent on an inquiry into the group as such and not just its Othering. If we knew nothing about Muslims, we would have no way of knowing when they were being Othered. Moreover, we could have no basis for refuting or limiting the power of stereotypes, racist generalisations and other forms of 'Othering'. I am reminded here of Dervla Murphy's wise words: 'of those whom we know nothing, we will believe anything' (Murphy 1987).

Of course, a group and its Othering are sometimes not easily separated and certainly interact. My point is that a group may be, and usually is, more than just an Other; the fact of interaction between the Othering of Muslims and non-Othered Muslimness does not limit the possibilities of being a Muslim to the tropes of Othering. Moreover, while such alterations and cross-influences will be happening all the time, we must not assume that they are all bad, all exercises of malign power. Which means that we need 
a normative framework or at least a reference point to judge the benign from the malign exercises of power or social effects. This takes me to my next proposition.

4. Critique of Othering presupposes a normative framework which needs to be justified.

Othering nearly always identifies the group in question in terms of negative features. Some of the most common have to do with having lower intelligence, being less capable of disciplined, responsible behaviour, and with a propensity for criminal or violent behaviour. In relation to Muslims, some of the negative traits are: an obsession with religion over other aspects of life, moral conservatism, especially in relation to sexuality, patriarchy, a tendency to act on religion or politics in extreme and violent ways.

Analysis of Othering is clearly an important tool when it can be deployed to show the operation of these negative perceptions in the media, in news reports, in political discourses and the way public concerns are raised and expressed (for example, in relation to 'radicalisation' or women's dress), in television programme content, in the activities of the security services and so on. There is, however, a limitation to such analyses of Othering or racialisaton. Namely, that sometimes there is a lack of agreement between those doing the Othering and those being Othered about whether certain features are necessarily negative. Most people will agree that to describe a group as less intelligent is to have said something negative about it. But is this the case with religious strictness and moral conservatism? Here it is possible that the dominant group may take one view of the matter-namely, that such attitudes and behaviours are negative and backward - but the minority, that is to say, substantial numbers within the minority, may refuse that such characterisations are negative. In recent years, we have seen this most starkly in Europe, in the dominant society's view that wearing the hijab or the burqa by Muslim women is a sign of oppression (Göle \& Billaud 2011). Despite the dominant society delivering this judgement through the popular and intellectual media, the numbers of women engaged in such practices have increased and the increase has been accompanied by the women in question saying that they are choosing to don such clothes out of choice and not as compliance with the demands of Muslim men. To accept, to qualify or to resist such Muslim women's perspective is not just a matter of empirical inquiry, but invokes a normative framework. In recent years aspects of feminism and liberalism (for example, 'Western feminism' and 'muscular liberalism') have been cynically and insincerely used to critique and undermine various Muslim practices and claims for accommodation, including issues of women's dress (Göle \& Billaud 2011, Phillips 2007, Scott 2009). However, not all such appeals have to be cynical or insincere. They can be principled and reasonable. I will say more about the sincere and insincere versions below. I am at the moment simply making the point that some such normative framework is necessary. 
An analysis of Othering, for example, of how the fact of living within a hegemonic secularism subtly influences Muslim subjectivity, is incomplete without an appeal to a normative framework, for without that we cannot know to what extent the influence is a result of an exercise of self-interested power, of domination, and to what extent it is an aspect of benign social change on the part of Muslims themselves, who on a reasoned basis come to adapt their practices and modify their sense of what it means to be a Muslim. To stick with my earlier example, to argue that the hijab or the burqa are or are not a form of oppressive Othering is not just a matter of empirical inquiry or discourse analysis but implicitly or explicitly appeals to how to distinguish between what is negative and what is positive in the characterisation of Muslims. If it is implicit, it needs to be made explicit. Either way the normative presuppositions need to be questioned; that is to say, they cannot be taken for granted but stand in need of argument and justification. Without such justification, not only may an analysis of Othering be incomplete or distorted, but it may itself be an exercise in Othering, namely in seeing groups in question as prejudicially Othered as, for example, religious conservatives, when that is exactly how (some of) the group may wish to think of itself and to be respected for being as such. This will of course be an empirical matter: hence my earlier point that critique of Othering presupposes empirical knowledge of the Other. But, depending on the facts, it may also be a refusal to accept the group on its own terms. That may not be wrong as such. My point is that to accept or not to accept will require a normative argument and so a perspective such as Orientalism or anti-Islamophobia is incomplete without normative argument. So, the kind of normative disavowal that one finds in the influential work of, say, Talal Asad $(2003,2009)$ is misplaced. He has been a powerful force for getting us to rethink secularism, but his conceptual framework does not explicitly help us to determine whether secularism is a good thing, or which version of secularism is better than another. Or, to put it another way. Everyone will agree that Islamophobia must be distinguished from reasonable criticism of Muslims and aspects of Islam, but not only is this a difficult distinction to make but it begs the question what are reasonable criticisms that Muslims and non-Muslims may make or discuss in relation to some Muslim views about say gender or education or secularism. Not only must the study of Islamophobia not squeeze out the possibility of such discussion, but by showing us where it becomes Islamophobic it should help to guide us onto the terrain of reasonable dialogue. Merely identifying the unreasonable and the populist is not enough; our frames of analysis should lead us to the reasonable, to what criticisms may be made of Muslims and/or Islam and what criticisms that Muslims want to make of contemporary Western societies too are worthy of hearing. The minority in question must be able to negotiate, modify, accept criticism and change in its own way; a dialogue must be distinguished from a one-sided imposition. 
Islamophobia should therefore be studied within a normative framework and not just one that exposes the normative presuppositions of others while evading the challenge of justifying one's own normative presuppositions. My own framework, multiculturalism or a struggle for recognition and institutional accommodation, prioritises groups fighting negative outsider perceptions by giving normative and political weight to insider identifications in all their plurality (Modood 2013 [2007]).

5. Islamophobia can be distinguished from reasonable criticism of Islam and Muslims.

Yet, how, it may be asked, are we to distinguish reasonable criticism from Islamophobia? Take the proposition:

Muslim views about women are oppressive and not appropriate for modern Britain.

Is this Islamophobia or reasonable criticism?

My suggestion is that we should apply the following five tests:

1. Does it stereotype Muslims by assuming they all think the same?

Does the criticism seem to suggest that all or most Muslims have this blameworthy characteristic and that this feature defines Muslims, indeed drowns out any worthy characteristics and ignores contextual factors?

2. Is it about Muslims or a dialogue with Muslims, which they would wish to join in?

Does the mode of criticism consist of generalising about a group in a way that tends to exclude them rather than treat them as conversational partners who share common concerns?

3. Do the terms of the debate allow possible mutual learning?

For example, one may criticise some Muslims for sexual conservatism or puritanism but is one willing to listen to those Muslims who think that contemporary societies like Britain are over-sexualised and encourage sexually predatory and undignified behaviour?

${ }^{7}$ In the post-Harvey Weinstein and \#MeToo climate it might be easier to understand the point here than it might have been a few years ago. 
4. Is the language civil and contextually appropriate?

Is the behaviour or practice being criticised in an offensive way and seems to make Muslims the target rather than stick to the issue? (A good analogy is here is how reasonable, contextual criticism of Zionsim can become a diatribe against Jewish people as such.)

\section{Insincere criticism for ulterior motives?}

Does the person making the criticism really care about the issue or is the person using it to attack Muslims (in the way that some have come to use feminism and homosexuality)?

If the answer to questions 1 and 5 is a 'Yes' or a 'No' to 2, 3 and 4, then we may be dealing with Islamophobia or anti-Muslim racism. Any discourse can of course have a mixed character, but the more the answer aligns with the pattern mentioned, the more that discourse needs to be examined closely as to its potentially Islamophobic character. This of course is not a litmus test with a single decisive colour result. I hope, however, it indicates what we should be looking for and why and so can be the basis for a discussion about whether a particular discourse is Islamophobic or reasonable criticism. The thread running through these questions is whether there is a potentialinvited or uninvited - for dialogue with Muslims. It is questions like these that should determine what 'Others' Muslims and what is capable of becoming a dialogue, albeit a critical dialogue, with Muslims.

\section{CONCLUSION}

The public career of the concept of Islamophoba was launched by The Runnymede Trust in 1997. I have offered an alternative understanding of Islamophobia that does not locate it in the field of religious tolerance and pluralism; rather, as anti-Muslim racism in the context of multicultural citizenship. This concept is becoming established in social science and public discourse. I have, however, expressed some misgivings about an aspect of the direction that some Islamophobia/Muslim studies are taking. Racialised ethno-religious groups have an 'inside', but in much of social science are understood as 'constructed from the outside' or as a form of 'Othering'. Both these aspects of groupness have a real-world existence and political significance, and cannot be reduced to each other. Inquiries focused on 'Othering' alone are therefore onesided and incomplete. They may be motivated by an urgent anti-racism but, by leaving aside Muslim subjectivity and agency, they may in the long run diminish the status of Muslims. Moreover, an appreciation that perceptions and criticisms of Muslims and 
Islam cannot be reduced to 'Othering' allows us to acknowledge that criticising Muslims is not intrinsically unreasonable or racist. I have distinguished between Islamophobia and reasonable criticism of Muslims by emphasising the importance of dialogue. If this use of multiculturalist concepts of cultural racism, identity recognition and dialogue can help us to grasp the core and limits of the concept of Islamophobia, it might be an indication that multiculturalism is not dead but has a vital contribution to make on contemporary problems around diversity. This article is thus a multiculturalist plea for studying Islamophobia (and groups negatively perceived from the outside, generally) within a normative framework based on the importance of boosting insider identifications for groups fighting outsider perceptions. It is a sociology driven by socio-political problems and which thinks of problems and solutions as existing within a common intellectual framework. This framework must be normative, for to identify something as a problem, let alone to address it is to appeal to normative ideas. Going further, normative sociology uses sociological enquiry to engage with ideals and to justify itself normatively. It thus has an active interdisciplinary rather than a merely dependent relationship upon political theory. It is a form of sociology that lends itself to and prizes public intellectual engagement. The aim of the article has been to simultaneously present a distinctively multiculturalist approach to understanding and responding to Islamophobia and a way of doing sociology. ${ }^{8}$

\section{REFERENCES}

Allen, C. (2010), Islamophobia (Farnham, Ashgate).

APPG (All Party Parliamentary Group on British Muslims) (2018), Islamophobia Defined: Report on the Inquiry into a Working Definition of Islamophobia / Anti-Muslim Hatred.

https://static1.squarespace.com/static/599c3d2febbd1a90cffdd8a9/t/5bfd1ea3352f531a6170ceee/ 1543315109493/Islamophobia+Defined.pdf (last accessed 31/12/2019)

Asad, T. (2003), Formations of the Secular: Christianity, Islam, Modernity (Stanford, CA, Stanford University Press).

Asad, T. (2009), Genealogies of Religion: Discipline and Reasons of Power in Christianity and Islam (Baltimore, MD, Johns Hopkins University Press).

BBC News (2019), 'Government Rejects Islamophobia Definition Ahead of Debate', 15 May. https://www.bbc.co.uk/news/uk-politics-48283337 (last accessed 31/12/2019).

Brubaker, R. (2005), Ethnicity Without Groups (Cambridge, MA, Harvard University Press). https://doi.org/10.1017/CBO9780511489235.004

CBMI (Commission on British Muslims and Islamophobia) (1997), Islamophobia: A Challenge For Us All (London, Runnymede Trust).

Dinet, E. \& ben Ibrahim, Sliman (1918), The Life of Mohammed, The Prophet of Allah (Paris, Paris Book Club).

${ }^{8}$ The wider multiculturalist position this belongs to is captured in Geoffrey Brahm Levey (2019) and the symposium that follows in the December, 2019 issue of Ethnicities. 
Dobbernack, J. \& Modood, T. (2015), 'Tolerance in Critical and Political Theory: Coexistence or Parts of Something Bigger?', Contemporary Political Theory, 14(2): 164-71.

Dobbernack, J. \& Modood, T. (forthcoming), 'Struggles for Tolerance and Recognition: Thinking with Democratic Multiculturalism', in K. Jensen \& A. Douglas (eds) Preston King: History, Method, Toleration and Friendship.

Elahi, F. \& Khan, O. (eds) (2017), Islamophobia: Still a Challenge For Us All. A 20th-anniversary Report (London, The Runnymede Trust).

https://www.runnymedetrust.org/uploads/Islamophobia\%20Report\%202018\%20FINAL.pdf

Ethnicities (2019), Symposium on the Bristol School of Multiculturalism, 19(6): 955-1014. https://doi.org/10.1177/1468796819840728

Göle, N. \& Billaud, J. (2011), 'Islamic Difference and the Return of Feminist Universalism', in A. Triandafyllidou, T. Modood \& N. Meer (eds) European Multiculturalisms: Cultural, Religious and Ethnic Challenges, (Edinburgh, Edinburgh University Press), 116-41

Hall, S. (1992a), 'The Question of Cultural Identity', in S. Hall \& T. McGrew (eds) Modernity and its Futures (Cambridge, Polity Press), 274-316.

Hall, S. (1992b), 'New Ethnicities', in J. Donald \& A. Rattansi (eds) 'Race', Culture and Difference (London, Sage), 252-59.

Johnson, B. (2018), 'Denmark Has Got It Wrong. Yes, The Burka Is Oppressive And RidiculousBut That's Still No Reason To Ban It', The Telegraph, 5 August.

https://www.telegraph.co.uk/news/2018/08/05/denmark-has-got-wrong-yes-burka-oppressiveridiculous-still/ (last accessed 23/12/2019).

Kristeva, J. (1981), 'Woman Can Never be Defined', trans. M. A. August, in New French Feminisms, E. Marks \& I. de Courtivron (eds) (New York, Schocken), 137-41.

Lægaard, S. (2008), 'Moderate Secularism and Multicultural Equality', Politics, 28(3): 160-8. https://doi.org/10.1111/j.1467-9256.2008.00325.x

Lægaard, S. (2009), 'Moderate Secularism, Difference Sensitivity and Contextualism: A Rejoinder to Modood', Politics, 29(1), 77-81. https://doi.org/10.1111/j.1467-9256.2008.01341.x

Lægaard, S. (2015), 'Multiculturalism and Contextualism: How Is Context Relevant for Political Theory?', European Journal of Political Theory, 14(3), 259-76. https://doi.org/10.1177/1474885114562975

Levey, G. B. (2019), 'The Bristol School of Multiculturalism', Ethnicities, 19(1): 200-26. https://doi.org/10.1177/1468796818787413

Massoumi, N., Mills, T. \& Miller, D. (eds) (2017), What is Islamophobia? Racism, Social Movements and the State (London, Pluto Press). https://doi.org/10.2307/j.ctt1rfsndp

Meer, N. \& Modood, T. (2012), 'How Does Interculturalism Contrast With Multiculturalism?', Journal of Intercultural Studies, 33(2): 175-96. https://doi.org/10.1080/07256868.2011.618266

Meer, N., Modood, T. \& Zapata-Barrero, R. (2016), Multiculturalism and Interculturalism (Edinburgh, Edinburgh University Press). https://doi.org/10.3366/edinburgh/9781474407083.003.0011

Modood, T. (1997), “ "Difference”, Cultural-racism and Anti-racism', in P. Werbner \& T. Modood (eds) Debating Cultural Hybridity: Multicultural Identities and the Politics of Anti-racism (London, Zed Books), 154-72.

Modood, T. (2005), Multicultural Politics: Racism, Ethnicity and Muslims in Britain (Minneapolis, MN, University of Minnesota Press and Edinburgh, University of Edinburgh Press).

Modood, T. (2009), 'Moderate Secularism and Multiculturalism', Politics, 29(1), 71-6. https://doi.org/10.1111/j.1467-9256.2008.01340.x

Modood, T. (2013 [2007]), Multiculturalism: A Civic Idea, 2nd edn, 2013 (Cambridge, Polity Press).

Modood, T. (2017), 'Islamophobia and the Muslim Struggle for Recognition', in F. Elahi \& O. Khan (eds) Islamophobia: Still A Challenge for Us All. A 20th-anniversary Report (London, Runnymede Trust), 66-8. 
Modood, T. (2018), 'Interculturalism: Not a New Policy Paradigm', Comparative Migration Studies, 6(1): 22. https://doi.org/10.1186/s40878-018-0091-5

Modood, T. (2019), Essays on Secularism and Multiculturalism (London, Rowman \& Littlefield International).

Modood, T. \& Thompson, S. (2018), 'Revisiting Contextualism in Political Theory: Putting Principles into Context', Res Publica, 24(3): 335-57. https://doi.org/10.1007/s11158-017-9358-1

Mr Moo (2006), Notes on Islamophobia, Yahya Birt, 31 December.

https://yahyabirt1.wordpress.com/2006/12/31/notes-on-islamophobia/ (accessed on 23/12/2019).

Murphy, D. (1987), Tales from Two Cities (London, John Murray).

Oakeshott, M. (1962), Rationalism in Politics and Other Essays (London, Methuen).

Phillips, A. (2007), Multiculturalism Without Culture (Princeton, NJ, Princeton University Press).

Rana, J. (2007), 'The Story of Islamophobia', Souls, 9(2): 148-61. https://doi.org/10.1080/10999940701382607

Said, E. W. (1995 [1978]), Orientalism: Western Conceptions of the Orient (London, Penguin Books).

Scott, J. W. (2009), The Politics of the Veil (Princeton, NJ, Princeton University Press).

Sheridan, L. P. (2006), 'Islamophobia Pre- and Post-September 11th, 2001', Journal of Interpersonal Violence, 21(3): 317-36. https://doi.org/10.1177/0886260505282885

Shils, E. A. \& Finch, H. A. (trans. and ed.) (1997), The Methodology of the Social Sciences (1903-17) (New York, Free Press).

Spivak, G. C. (1990), The Post-colonial Critic: Interviews, Strategies, Dialogues (London, Routledge).

Wike, R., Poushter, J., Silver, L., Devlin, K., Fetterolf, J., Castillo, A. \& Huang, C. (2019), European Public Opinion Three Decades After the Fall of Communism (No. 6: Minority Groups), Pew Research Center.

https://www.pewresearch.org/global/2019/10/14/minority-groups/ (last accessed 23/12/2019).

Wittgenstein, L. (1953), Philosophical Investigations (Oxford, Blackwell).

Acknowledgements: This is an expanded version of the second British Academy Sociology Lecture, given on 20 March 2019. In modified and extracted forms it has been used as a basis for various talks since 2014 and was used as a basis for my short contribution to the Runnymede Report (Modood 2017); to a short submission to the All-Party Parliamentary Group on British Muslims in response to the call for evidence on 'Working Definition of Islamophobia, 1 June 2018: https://www.academia. edu/36775691/Islamophobia_A_Form_of_Cultural_Racism; similarly to the House of Commons Home Affairs Select Committee Inquiry on Islamophobia, 4 September 2019: http://data.parliament.uk/writtenevidence/committeeevidence.svc/evidence document/home-affairs-committee/islamophobia/written/104325.pdf; and to parts of my book, Modood (2019).

To cite the article: Tariq Modood (2020), 'Islamophobia and normative sociology', Journal of the British Academy, 8: 29-49.

DOI https://doi.org/10.5871/jba/008.029

Journal of the British Academy (ISSN 2052-7217) is published by

The British Academy, 10-11 Carlton House Terrace, London, SW1Y 5AH

www.thebritishacademy.ac.uk 
